\title{
The Validity of Walras' Law in a Monetary Exchange Economy: Money, Prices and the Integration of Monetary and Value Theory
}

\author{
Narciso TÚÑEZ AREA \\ narcisotunez@gmail.com
}

Received: 22/02/2015

Accepted: 20/05/2015

\begin{abstract}
Resumen
La Ley de Walras es uno de los principios más importantes de economía Neo-liberal. Se supone que es una Identidad Tautológica en la que en economías de mercado el desequilibrio tiene una naturaleza compensatoria. Por tanto, el desequilibrio en cualquier mercado implicaría un desequilibrio en otra parte del sistema. Sin embargo, en los sistemas monetarios las mercancías no se intercambian por mercancías, es decir, no son substitutas del dinero. Cuando las restricciones presupuestarias tienen en cuenta el problema de la realización asociado al no cumplimiento del Axioma de Substitución Bruta Clásico, resulta que el desequilibrio no es compensatorio. Así, este artículo demuestra que La ley de Walras no siempre cumple.
\end{abstract}

Palabras clave: Ley de Walras, Axioma de Sustitución Bruta, restricciones presupuestarias, problema de la realización, desequilibrio compensatorio

\begin{abstract}
Walras' Law is one of the most important tenets of Neo-liberal economics. It is supposed to be a Tautological Identity according to which disequilibrium in market economies has a compensatory nature. Hence, disequilibrium in any market would imply an opposite imbalance somewhere else in the system. However, in monetary systems commodities do not buy commodities, i.e. they are not substitutes of money. When budget constraints take into account the realization problem associated with the violation of the Classical Gross Substitution Axiom, disequilibrium turns out to be non-compensatory. This paper shows that Walras' Law does not always hold.
\end{abstract}

Key-words: Walras' Law, Gross Substitution Axiom, budget constraints, realization problem, compensatory disequilibrium

JEL Classification: B12, B13, B22, E5, D50

\section{Introduction}

Leon Walras (1834-1910) was the first economist to formalize the system of inter-sector relationships within the economy in an integrated mathematical model. He conceived the economic system as a collection of different inter-related markets that influence each other and individuals interacting within them. Every individual has a budget constraint that comprises his initial endowment of resources within the period under analysis. Each one is assumed to demand resources according to the Principle of Utility maximization given his original endowment of resources. The summation of budget constraints for every individual in the economy results in the well-known identity equation stating that the summation of excess demand must be zero. According to this principle the labour market cannot remain in a state of Unemployment Equilibrium as one other market must at least be in disequilibrium. Hence, Unemployment Equilibrium is ruled out as a theoretical possibility. This statement is clearly at odds with Keynes' original thesis. Because Walras' Law is considered an identity, i.e. an uncontested law in economics, those who defend the coherence of Keynes' insights are faced with the challenge of juggling both conflicting theoretical constructions. This apparent contradiction between unemployment equilibrium and Walras' Law led Leijonhufvud to re-define Keynesian Unemployment Equilibrium (KUE) as Unemployment Disequilibrium. For Palley this contradiction does not exist. "Recognizing the monetary dimension to transacting, restores consistency of the Keynesian model with Walras' Law" (Palley 1997, p. 9). Or in other words, Keynesian unemployment equilibrium ceases to exist as unemployment will be always matched by an excess demand for money. The same approach is given in Keen (2011) where the invalidity of the equilibrium con- 
ditions derived from Walras' Law seems to be due to the assumption that Money is exogenous. However, the application of Walras' Law to a credit economy would result according to Keen in a "Walras-Schumpeter-Minsky Law". For Maurer (2009), Walras' Law does not hold but as we will see in section 2 he confuses Say's Identity with Walras' Law. Therefore, the invalidity of Walras' Law is crucial for the Re-instatement of the KUE thesis.

The purpose of this paper is not to give a complete account of Walras' models but to argue that in a monetary economy Walras' Law is a special case of a more general exchange law and only valid in situations where dis-coordination between economic agents cannot occur. Therefore it demonstrates that Walras' Law does not hold in disequilibrium and reinstates Keynes' original Unemployment Equilibrium theory as a theoretical possibility. The simple Patinkin' monetary exchange economy will be used to this purpose.

The paper will be structured as follows. Section 2 will outline the basic framework from which Walras' Law is derived and it will present a brief account of Clower's and Morishima's critiques of Walras' Law and why they have not represented a fundamental change in methodology. In section 3 the budget constraints are amended to represent a monetary economy which leads to the General Law of Exchange and this underlying framework is analysed for a two individuals - two commodities system and in section 4 the conclusion.

\section{Walras' Law}

Walras developed his general equilibrium models progressively in five parts and although more complex models are introduced in later chapters, already in Part II: "Theory of Exchange of Two Commodities for Each Other", he was working out the basic principles of Walras' Law. He stated that the value of the commodities exchange must be equal to each other ${ }^{1}$ and that the excess demand of one commodity plus the excess demand of the other commodity must be equal to zero. We can see then how the basic principles of exchange are already unfolding the elemental foundation of Walras' Law, yet not fully developed. In Part III the "Theory of Exchange of Several Commodities for one Another", Walras incorporated several commodities and markets. Walras' general framework has been applied to a barter economy where the demand of any commodity implies the supply of any other commodity of equal value. Indeed, he introduces fiduciary media in Part VI "Theory of Circulation and Money" after having analysed the theory of production and the theory of capital formation and credit, parts IV and V respectively.

In a barter economy individuals will demand commodities as long as they still have commodities ready to be supplied. Consequently, any excess supply of commodities is by definition a demand for commodities itself. However, in monetary economies there is a need to transform commodities into Money for the system to reproduce itself. ${ }^{2}$ Without monetary transformation of commodities into money the system breaks down. Economic crisis are thus observable facts that cannot be dealt with in a moneyless system. Hence, we are taking the methodology in Patinkin (1965) of starting off from a monetary exchange economy for setting up the basic equations of monetary exchange within a general equilibrium framework before dealing with production or capital formation. ${ }^{3}$ In Patinkin's monetary exchange system there are two different types of markets, Money and Non-Monetary Markets. Money is supposed to be the kind of

\footnotetext{
1 "Having recourse now to algebraic notations, let us say that holder (1) of a quantity qb of commodity (B) comes to the market to exchange a quantity ob of (B), in return for a quantity da of (A) which he is ready to take in conformity with the equation $d_{a} v_{a}=o_{b} v_{b}$, and that he leaves the market carrying away a quantity da of (A) and a quantity y of (B), such that $y=q_{b}-o_{b}=q_{b}-d_{a} \frac{v_{a}}{v_{b}}$." (Walras 1854, p. 93). By Walras (1874), it is meant Jaffe's (1954) translation of the original.

2 Applying Marxist terminology it would correspond to the Realization Problem.

3 "Let us now extend the foregoing analysis to the case of an exchange economy with money...The individual's initial endowment of goods Monday morning is now assumed to fall into two mutually exclusive and exhaustive categories: commodities and money" (Patinkin 1965, p.13).

${ }^{4}$ Although endogenous, inside money or credit money can be introduced to obtain a more general statement of Walras' law.
} 
fiat paper money, also referred to as "outside money" by Gurley and Shaw (1960). The special treatment that we are giving to Money is due to the fact that any transaction on one of the NonMonetary Market will have a correspondent flow in the monetary one as stated by Palley (1997). There will also be $n$ agents in the economy and $m$ markets, $m-1$ non-monetary markets plus the money market. The initial Endowment of the individual-n will be defined by the vector $\bar{Y}_{n}=\left(\bar{Y}_{n}^{1}, \ldots, \bar{Y}_{n}^{m-1}, \bar{M}_{n}\right)$ and it will be composed by the initial supplies of the individual-n in the $m-1$ non-monetary markets plus his initial supply of money balances. The Initial Total Supply in the $m-1$ non-monetary market will be defined as $\bar{Y}^{m-1}=\left(\bar{Y}_{1}^{m-1}, \ldots, \bar{Y}_{n}^{m-1}\right)$ and the Initial Total Supply of Money $\bar{M}=\left(\bar{M}_{1}, \ldots, \bar{M}_{n}\right)$. Patinkin did not include the services of availability of commodities and money as having a different market from the original one. This procedure can be justified on two grounds. First, when commodities are consumed within the same period, the services that these commodities render to their holder will be demanded and consumed also by them. Hence, there will not be market of commodities services of availability. Secondly, Walras assumed a weak relationship between the price of the services of availability of money $\left(p_{m}^{\prime}\right)$ and the demand for money which might be due to the assumption of certainty in the money market.

If every individual holds exactly ${ }^{5}$ the amount of money he needs for the transaction of commodities and therefore maximizing the utility he obtains from holding cash balances, the monetary equations will fall outside the system of general equilibrium equations. For Walras the introduction of cash holdings into the utility function ${ }^{6}$ was a keystone into the proper integration of money and value theory. Although Patinkin criticised Walras' "encaisse désirée" for being introduced in nominal terms as it would constitute "(...) a willingness to ignore the influence of variations in the absolute price level on the other markets" (Patinkin, 1965, p. 569). This reflects Patinkin's necessity of the real cash balance effect for a coherence integration of money and value theory. However, Samuelson (1969) noted that this coherence could be achieved by a "dynamic adjustment of price ratios" in commodity markets without needing to include real cash balances in the utility function as Patinkin. ${ }^{7}$ Although there are some differences between Patinkin's and Walras' version of General Equilibrium, ${ }^{8}$ both asserted that initial endowments does determine the individual's demand for commodities. Hence, individual budgets are constrained by initial endowments which lead to a constrained system of equation. It is actually this common feature of Patinkin and Walras' models that this paper is arguing against.

If we let $Y_{n}=\left(Y_{n}^{1}, \ldots, Y_{n}^{m-1}\right)$ be the demand for supplies in non-monetary markets by the $\mathrm{n}$ individual, $M_{n}$ the demand for money by the n-individual and $p=\left(\begin{array}{c}p_{1} \\ \vdots \\ p_{m-1}\end{array}\right)$ the price vector the nominal value of $Y_{n}$ will be equal to $Y_{n} p=\left(Y_{n}^{1}, \ldots, Y_{n}^{m-1}\right)\left(\begin{array}{c}p_{1} \\ \vdots \\ p_{m-1}\end{array}\right)$. The market demand in non-monetary markets will be the sum of all the $n$ individual different demands $Y^{m-1}=$ $\left(Y_{1}^{m-1}, \ldots, Y_{n}^{m-1}\right)$ and the market demand for money the sum of all the $\mathrm{n}$ individual different demands for money $M=\left(M_{1}, \ldots, M_{n}\right)$.

\footnotetext{
${ }^{5}$ However, Walras would put it "almost" exactly. Therefore, for Walras "it comes very close, in reality, to falling outside the system of equations of general equilibrium" (Walras, 1954: p. 326). No tâtonnement is required in the money market because everyone is holding what they demand! Something that Patinkin viewed as a lack of coherence in the theoretical integration of money and value theory.

${ }^{6}$ Which nevertheless, he did not do until the fourth edition of his Élements.

${ }^{7}$ Further variations of money in the utility function models can be seen in Gali (2008).

${ }^{8}$ The analysis of these differences will only be slightly mentioned here. Yet, this paper does not intend to criticize the coherent integration of monetary and value theory in Walras' theoretic model. On the contrary it can be argued that Walras did integrate them in a coherent way, i.e. the demand for money and commodities result from utility functions coherently and each price can be determined by the interaction of supply and demand in their market. However, this integration is only theoretically valid in equilibrium.
} 
The market Excess demand in the $m-1$ non-monetary market is therefore the sum of all the different individuals' excess demands $E^{m-1}=\left(E_{1}^{m-1}, \ldots, E_{n}^{m-1}\right)$ and its nominal amount $E^{m-1} p_{m-1}$. The market Excess demand for money will be the sum of all the individuals' excess demand for money $E^{m}=\left(E_{1}^{m}, \ldots, E_{n}^{m}\right)$. Adding up the individual excess demand equations we can obtain the well-known statement in equation (2.1) that the sum of all excess demands for all the markets must be equal to zero. Walras' Law is then a direct conclusion from the budget constraint, a conclusion that could be obtained without any reference to Utility maximization. As Harris stated "Walras' Law is derived from the individuals' budget constraint" (Harris, 1981, p. 53).

$$
\text { (2.1) } \sum_{i=1}^{n} \sum_{j=1}^{m-1} E_{i}^{j} p+\sum_{j=1}^{n} E_{j}^{m}=0 \quad \text { or } \quad \sum_{j=1}^{m} E^{j} p+E^{m}=0
$$

Furthermore, within the Walrasian period the tatonnement is supposed to bring about the equilibrium level of prices. We could interpret the static Walrasian period as the exact stage in the adjustment process in which all the changes in the endogenous variables have taken place and therefore adjusted themselves to the dynamic forces of competition. Walras' positive interpretation of dynamic adjustment allowed him to analyse the interrelationships among different markets and individuals in this particular temporarily frozen system of equations in a moment in time when output and prices are equal to their equilibrium level. Tâtonnement ensures that disequilibrium is temporary as the allegedly inherent dynamic tendency of market economies pulls the system towards equilibrium. Furthermore, if the speed of adjustment to the optimum equilibrium path is fast enough the assumption that trade happens at clearing prices might in fact be realistic. However, the adjustment to equilibrium implies already a departure from the original exchange equations. Tâtonnement might have been for Walras simply a convenient expression of the analytical exposition of dynamic change. Yet, this expression did not reflect itself the departure from the equilibrium position as the realization problem is not considered. ' Walras' exchange equations do not reflect disequilibrium processes or the adjustment to equilibrium that take place in historical time. Historical time is taken by Walras at the exact moment in time when markets and individuals have adjusted towards the equilibrium state. In equilibrium individuals would have to hold an increased amount of money if they expect a higher mismatch between sales and purchases receipts ${ }^{10}$ as the satisfaction from holding cash balances is derived from the services money give in allowing the purchase of supplies in advance of receipts from the sales of production. This need remains even in the case of perfect information and certainty and it is derived from the role of money as the only mean of exchange. He assumed certainty in the money market as he expected individuals to hold the optimum amount of cash balances at all times. ${ }^{11}$ This assumption might be reasonable when the basic uncertainty for current sales in the commodity market is the result of the role of money as a medium of exchange but not when money is used as well as a store of value.

In equilibrium individuals sell everything they have planned to sell and hold enough cash balances as to cover the gaps between outlays and receipts. However, Foley (1975) has challenged the concept of equilibrium and the validity of Walras' Law by assuming that the specification of equilibrium is ill-formed. Hicks (1965), Buiter (1975) and Yeager and Rabin (1997) have already argued against the existence of two different equilibrium conditions for stocks and flows. Hence, it will also be assumed that "(...) transactions-flow equilibrium means that desired market purchases equal desired sales (...) including adjustments of holdings" (Yeager and Rabin 1997, p.23). Therefore, equilibrium is meant to include both stock and flow transactions

\footnotetext{
${ }^{9}$ The realization problem will be explained in sections 3 and 4 below.

${ }^{10}$ That is according to the probability distribution of the payment process.

11 "There may be a small element of uncertainty which is due solely to the difficulty of foreseeing possible changes in the data of the problem. If however, we suppose these data constant for a given period of time and if we suppose the prices of goods and services and also the dates of their purchase and sale to be known for the whole period, there will be no occasion for uncertainty" (Walras 1954, p. 317).
} 
as Hicks would put it "We do not need to distinguish between stock and flows..." (Hicks 1965, p. 85).

In disequilibrium, the true uncertain nature of monetary economics is reflected in the fact that individuals do not know how much they would be able to sell and buy and hence they are uncertain about how much they have to hold in cash balances to cover the gaps between outlays and receipts. At equilibrium prices, all markets clear and the aggregate value of excess demands for all individuals and markets are zero. However, at different than equilibrium prices, by the application of Walras' Law, we are led to view markets as counterbalancing systems where disequilibrium is coordinated and compensatory. It is indeed this type of coordination that Clower was arguing against. Clower (1969) stated that Walras' Law only applies to full employment states “(...) Walras' Law although valid as usual with reference to notional market excess demands, is in general irrelevant to any but full employment situations. Contrary to the findings of traditional theory, excess demand may fail to appear anywhere in the economy under conditions of less than full employment" (Clower 1969, p. 292).

However, Clower's demonstration has been shown to be bleak by Rhodes: "It has now been established that Walras' Law holds in both the notional and in the effective sense. This is true both in and out of general equilibrium. When we speak of disequilibrium we must be careful to indicate the sense in which we are using the term" (Rhodes, 1984, p. 121). Rhodes (1984, 1990) asserts that Clower (1969) refers to a particular version of the Walras' Law. This "rational planning postulate" has been referred to by Clower and others as "Say's Principle". Clower himself recognises that there is no formal differentiation between Say's law and Walras' Law. "The distinction drawn by Lange between Walras' Law and Say's Law is not relevant here; from a formal point of view, the two propositions are equivalent" (Clower 1971, p. 275). Contrary to Clower's proposition, the formal difference between those two expressions can be seen in Patinkin (1965):

Following Lange, we define Says' Identity as stating that-regardless of the prices and interest with which they are confronted -individuals always plan to use all of their proceeds from the sale of commodities and bonds. In other words they never plan to change the amount of money they hold: its amount of excess demand is identically zero. In still other words -and as a direct consequence of the budget restraint- the aggregate value of the amounts of excess supply of commodities must always equal the value of the amount of demand for bonds. (Patinkin, 1965, p. 193).

In Lange (1942) original work only the commodities and money markets are considered, therefore, Walras' Law in Clower's sense or Say's Identity ${ }^{12}$ in the sense of Lange as defined by Patinkin leads to the conclusion that the excess demand for commodities is equal to zero. Therefore Say's Identity in the Lange sense will not be valid in monetary economies as the money market might not clear. "Hence we can say that the existence of Say's Identity implies the existence of a barter economy (...) [Say's Identity] necessarily absent from a money economy" (Patinkin 1965, pp. 194-195). This confusion between Says' Identity and Walras' Law can also be seen in Maurer (2009). He takes "Walras' Law according to the definition of Patinkin (1965)" (Maurer 2009, p. 3). However, in both inside and outside money models, he states that Walras 'Law does not hold even when the excess demand for commodities is equal to the excess supply of money which according to Patinkin fulfils the definition of Walras 'Law. Hence, what Maurer shows is that Say's Identity only holds in barter economics and not the invalidity of Walras 'Law.

As Maurer, Clower's attempt to demonstrate the invalidity of Walras' Law faulted in showing the formal difference between Say's Identity and Walras' Law. Although in Clower's case it was the consequence of not having analysed the distinctive nature of a monetary economy. On

\footnotetext{
${ }^{12}$ Says' Identity refers to the short run equality of supply and demand for commodities and Say's law referring to the assumed long run equilibrium between supply and demand for commodities. See Kates (1997). Hence, for our purpose the theoretical difference between Say's Identity, Say's Principle or Say's Law is not relevant here as they all mean equilibrium in commodity markets.
} 
the other hand, Clower relied on Walras' production model where the existence of supernormal profits in disequilibrium is viewed by Clower as a proof of the invalidity of Walras' Law. In equilibrium supernormal profits are assumed to be zero. However, Clower's valid point was that in disequilibrium, due to the existence of supernormal profits, the summation of excess demands would not be zero. This point was taken up by Rhodes (1984) to suggest that the supernormal profits represent an excess demand for fixed capital and therefore that Walras' Law still holds. For Rhodes firms' expected profits represent their demand for productive capital. An implicit assumption in Rhodes (1984) is that individuals are the only suppliers of capital. ${ }^{13}$ In such a case the profits that are expected to be received will be owned by individuals and hence represent the supply of capital available to firms. This point can also be seen in Morishima (1977). As a matter of fact, if this condition is not satisfied, Morishima clearly shows that Walras' Law does not hold when there are supernormal profits. "Thus we find that Walras' Law does not hold in the original system of general equilibrium of production due to Walras. This rather paradoxical conclusion that Walras' Law system does not satisfy the Walras' Law is also true for his growth and money models, so that, strictly speaking, we must say that Walras did not know Walras' Law" (Morishima 1977, p. 48).

To correct Walras' Law Morishima assumed that supernormal profits are distributed among individuals and therefore part of the new budget constraint. "In order to correct Walras' model so as to fulfil Walras' Law let us assume that the aggregate excess profit is distributed among individuals, say, in proportion of their ownership of capital goods (...). In view of the revised budget equation (6), we can easily verify that these excess demand functions satisfy Walras' Law..." (Morishima 1977, p.50). According to Morishima when budget constraints are corrected the validity of Walras' Law is reinstated. Nevertheless the budget constraints need to be amended as to represent a productive monetary economy. In the next section the budget constraints are adjusted accordingly for the case of a monetary exchange economy.

\section{The General Law of Exchange}

Neither Maurer's, Clower's, Foley's nor Morishima's critique have therefore represented a challenge to the validity of Walras' Law. This section does challenge it by examining the consequences of relaxing the classical perfect substitutability theorem in formulating the budget constraint equation for any individual in the system. It will be shown that in disequilibrium Walras' Law ceases to be valid. Hence, Walras' Law is not an identity. Furthermore, it is argued that Walras' Law is a special case of The General Law of Exchange. When all markets clear, both laws lead to the same system. However, in disequilibrium it will be seen that the budget constraints do not lead to the same conclusion as they lead to a general equilibrium framework, i.e. to the compensatory nature of disequilibrium states.

As before there will be $n$ agents in the economy and $m$ markets, $m-1$ non-monetary markets plus the money market. The initial Endowment of individual-n will be defined by the same vector. In opposition to a Barter Economy where commodities are allowed to be exchanged for other commodities, in a monetary exchange economy individuals exchange commodities for money. Money is, therefore, the only medium of exchange to buy commodities. Hence, money buys commodities but commodities do not buy commodities. Therefore, the Gross Substitution Theorem does not apply ${ }^{14}$ which is a more realistic abstraction ${ }^{15}$ of monetary market economies. Individuals exchange equal amounts of Nominal Value. The Nominal Value of the Initial Endowment (INV) before exchange must therefore be equal to the Final Nominal Value (FNV) of the same Endowment after exchange has taken place at market prices. For any flow of real commodities among individuals there exists a monetary flow of equal nominal value to the flow of commodities at market prices.

\footnotetext{
${ }^{13}$ Which are referred to as residual earnings factors.

${ }^{14}$ See Davidson (1978).

${ }^{15}$ See Chick (1995).
} 
Let's assume that the endowment of any individual $\mathrm{n}$ can be separated in two groups: the Initial Endowment of Commodities $\bar{Y}_{n}=\left(\bar{Y}_{n}^{1}, \ldots, \bar{Y}_{n}^{m-1}\right)$ and the Initial Endowment of Money $\bar{M}_{n}$. Hence, the initial nominal value of individual-n's endowment $\left(I N V_{n}\right)$ would be equal to:

(3.1) $I N V_{n}=\bar{Y}_{n} p+\bar{M}_{n}$

(3.2) $F N V_{n}=\left(\bar{Y}_{n}-Y^{, n}\right) p+Y_{n} p+\left(\bar{M}_{n}+Y^{, n} p-Y_{n} p\right)$

After the exchange the FNV would be equal to the nominal value of commodities supplied by $n$ that remained in possession of individual $n$ plus the nominal value of commodities bought by him plus the final amount of money in his possession. It is worth noting that individuals do not know how much of their endowment they will be able to sell and therefore they also do not know how much they will be able to purchase. Hence, the essential characteristic of money as the unique medium of exchange brings up the underlying uncertainty inherent in monetary market economies that might restrict individuals from demanding the total nominal value of their endowment. Therefore, the budget constraint will not be determined by initial endowments.

The Effective demand for money $\left(M_{n}\right)$ is equal to:

$$
\text { (3.3) } M_{n}=\left(\bar{M}_{n}+Y^{, n} p-Y_{n} p\right)
$$

Although the individual adjusts his demand for commodities to make his cash holdings equal to the desired level, it is possible that both quantities might not be equal. Nevertheless, that would not affect the validity of the equation of exchange.

$$
\text { (3.4) } I N V_{n}=F N V_{n}
$$

$$
\forall \mathrm{p} \text { and } \mathrm{M}^{\mathrm{D}}
$$

Equation (4-4) could be called the General Law of Exchange (GLE). Indeed, this equation is an identity, a tautology in the sense of Yeager and Rabin (1997). When the Demand for nonmonetary goods has been fully adjusted to the desired demand for money $\left(M_{n}^{D}\right)$, we can obtain:

$$
\text { (3.5) } F N V_{n}=\left(\bar{Y}_{n}-Y^{, n}\right) p+Y_{n} p+M_{n}^{D}
$$

Furthermore, we can see that only when we introduced the condition that there are no unsold products $\left(\bar{Y}_{n}-Y^{, n}\right) p=0$ into the GLE we have just arrived at in equation (3.5) we are able to obtain Walras' Law. Walras' Law is, hence, a special case of the GLE, the case when all markets clear. Furthermore, we can see that the nominal value of the initial endowment must be equal to the nominal value of the final distribution of the endowment. That is due to the own inherent nature of monetary economies; that is the monetary exchange of commodity value for monetary value. In barter economies as long as an individual remains in possession of commodity value, the same commodity value in exchange for commodities will be demanded, i.e. there will be no problem of monetary realization. However in monetary economies, the same ownership of commodity value will not be transformed into a demand for commodity value unless it is transformed into money first. Hence, an individual's net demand will not hinge on his amount of initial endowment but on the amount of it that he can transformed into money in the market. Therefore, the Budget Constraint of any individual in a monetary economy must necessarily take into account the realization problem. Once Budget Constraints are adjusted, coordination failures are not compensatory, i.e. excess demands do not imply excess supplies in a different market as we can see in the next section.

\section{A Two Commodities-Two Individual Exchange Model}


To simplify the argument a two commodities-two individuals mode ${ }^{16}$ will be analysed in order to explain and visualize the invalidity of Walras' Law. Let us suppose a system formed by two individuals 1 and 2 each one producing one commodity, 1 produces $\mathrm{X}$ and 2 produces $\mathrm{Y}$. The demand for money will be supposed to have the following form: $M_{1}=k_{1} p_{y} Y$ and ${ }^{17} M_{2}=$ $k_{2} p_{x} X$.

The budget constraints respond now to the principle of non-substitutability between commodities and money, i.e. commodities do not buy commodities. ${ }^{18}$ The difference between Walrasian and GLE's budget constraints is that the former are restricted by initial endowments whilst the latter are not restricted by the initial endowment of commodities but on realized results as in the unrestricted system of equations (USE) (A1-5/6) in appendix A1.

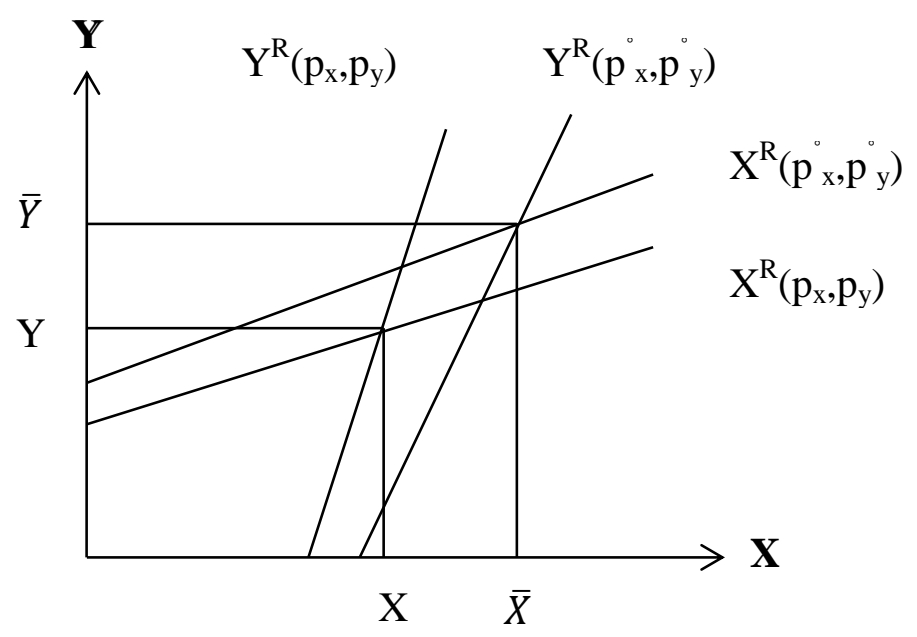

Figure 1: The Individual Reaction Functions

Equations (A1-7) and (A1-8) in appendix A1 are the reaction functions of individual 1 and 2 respectively which can be seen in Figure 1. These functions gauge the reaction of individuals' demands to changes in the demand for their own product. These equations simply indicate that the higher the sales of an individual are, the higher his expenditures will be. The solutions to the USE i.e. the unrestricted demand functions (UDFs), equations (A1-9/10), are homogenous of degree zero in accounting prices and hence absent of money illusion. ${ }^{19} \mathrm{~A}$ doubling of accounting prices and individuals money holdings has no consequence on the individuals demand for commodities. The price level in terms of the unit of account will also double and if demand functions were to depend on the price level no homogeneity would have been reached. ${ }^{20}$ Ac-

\footnotetext{
${ }^{16}$ The main features of the model will not be altered in an n-commodity - n-individuals model. Although, the demonstration of the convertibility to a general model is out of the scope of this paper, it does not compromise in any way the demonstration of the invalidity of Walras' Law which is established for the $2 \mathrm{c}-2 \mathrm{i}$ model.

${ }^{17}$ It will be assumed that the desired demand for money can be inferred from utility analysis in an integrated commodity and money model by introducing money into the utility function as in Patinkin (1965). Individuals are expected to obtain utility from holding positive amounts of the medium of exchange. Money services can be supposed to be bought through a special leasing contract where the buyer of the contract agrees to acquire money services for a determined period of time at a determined price. This contract guarantees that purchases are possible even when sales fall short of receipts in the short run. However, for Walras individuals know how much they will have to hold to guarantee their short term liquidity.

${ }^{18}$ The Unrestricted system can be seen in Appendix A1.

${ }^{19}$ From $\left(\mathrm{p}_{\mathrm{x}}, \mathrm{p}_{\mathrm{Y}}\right)$ a doubling of nominal prices would mean a new vector $2 *\left(\mathrm{p}_{\mathrm{x}}, \mathrm{p}_{\mathrm{Y}}\right)=\left(2 \mathrm{p}_{\mathrm{x}}, 2 \mathrm{p}_{\mathrm{Y}}\right)$.

${ }^{20}$ Condition for the classic tenant of monetary neutrality respect to equi-proportionate increases in nominal prices.
} 
cording to Patinkin this refers to the valid Classical Dichotomy where increases in accounting prices cause no effect on real variables. However, Patinkin asserts that there exists an invalid classical dichotomy in nominal prices if the demand functions of commodities where not to depend on the real cash balance effect but only on relative prices. The in-determination of nominal prices would lead to an internal contradiction as an infinite number of price levels would be coherent with equilibrium in the commodity market but not in the money market. This alleged contradiction reflects Patinkin's assumption that a "doubling of money prices causes a doubling of the amount of excess demand for money" (Patinkin 1965, p. 476) whilst the same would not interfere with commodities' relative prices. Therefore, it will preserve the equilibrium in the commodity markets but will create excess supplies in the commodity market which contradicts Walras 'Law. Hence, Patinkin asserted that demand functions for commodities need to depend on the real value of cash balances for the coherent integration of value and monetary theories. Although, he endorsed the alleged theoretical classical dichotomy between monetary theory and value theory as he defended that the price level will be determined in the money market by the interaction of Walrasian forces as "(...) value theory analyses market-experiments which do not [significantly] affect the absolute price level" (Patinkin 1965, p.181). On the contrary, this paper argues against this false theoretical dichotomy by proving that value and monetary theory are totally integrated, that Walras' Law does not hold in disequilibrium, that commodities' money prices are determined and that "money matters" in disequilibrium.

In equations (A1-16) it can be seen that at disequilibrium, higher than equilibrium nominal prices will preserve the equality between supply and demand for money. The increase in the commodities' nominal prices will cause the demand for commodities to half so that the equilibrium in the money market is not affected but leaving an excess supply of commodities. Hence, the real balance effect is not necessary to guarantee internal coherence as demands for commodities and money both depend on nominal prices. Additionally, individuals increase their consumption of commodities when either the nominal value of their cash balances increases or when the price they have to pay to obtain their preferred bunch of commodities decreases as Wicksell $(1898$, p. 40) already discussed: “(...) I therefore seek to enlarge my (cash) balance. This can only be done -neglecting for the present the possibility of borrowing-through a reduction in my demand for goods and service or through an increase in the supply of my own commodity.

This effect is also similar to Patinkin's real balance effect in that the real stock of money affects expenditure decisions. However, opposite to Patinkin's model, the real value of the money stock will be a subjectively ${ }^{21}$ relative value as it would depend on individuals' preferred bunch of commodities' nominal prices rather than on the average price level. The Walrasian price vec$\operatorname{tor}^{22}$, i.e. the combination of nominal prices that guarantees market clearing, can also be obtained when the UDFs are equal to the supply of commodities. Hence, at those prices the commodities and money markets do not exhibit excess supply or demands and Walras' Law becomes a special case of GLE when nominal prices reach the Walrasian equilibrium vector. At these equilibrium prices both constraint and unconstraint systems are equal. However, we can see that for a higher than equilibrium price vector the unrestricted demand functions for commodities are lower than the equilibrium ones, although the money market still remains with no excess demand. At disequilibrium prices there is indeed a Malthusian general glut that violates Walras' Law.

When $\mathrm{dx}=\mathrm{dy}=0$, the demands for commodities are equal to the initial endowment as in appendix A1. However, at higher than equilibrium prices the money market is still in equilibrium although there is an imbalance in the commodity market as some commodities cannot be sold. That is due to the fact that at these higher prices, the volume of sales has diminished as individuals cannot afford the equilibrium level of purchases at the current prices and individual preferences. In the appendix, equation (A1-15) resembles the Exchange Equation of the Quanti-

\footnotetext{
${ }^{21}$ See Burstein (1963).

${ }^{22}$ Equations (A1-11/12) in Appendix A1.
} 
ty Theory of Money (QTM) where income (Y) is the sum of the nominal value of total sales, income-velocity of money $(\mathrm{V})$ is the number of times that any unit of fiduciary media has to circulate to guarantee the exchange of the desired volume of sales and (M) is the demand for money.

If real output is determined by supply factors, an increase in (M) will only increase commodities' prices if $(\mathrm{V})$ is constant. ${ }^{23}$ This Ricardian assumption was the base of the Currency School that promoted the "currency principle" of tying the growth of outstanding fiduciary media to the growth of gold reserves. ${ }^{24}$ To this respect, The Peel's Charter Act $^{25}$ of 1844 that imposed the restriction to the Bank of England of having to back notes with gold reserves ${ }^{26}$ was a reflection of the victory of the Currency School in economic theory.

However, in equations (A1-9/10) we can see that at disequilibrium prices, the real output is not determined exogenously. Furthermore, when individuals are not constrained in the commodity markets we can also see that if the individual preferences for cash are equal to each other, the velocity of circulation is just the inverse of the collective preference for cash balances. However, in opposition to the QTM, far from determining the level of prices, it only explains the income-velocity of money in the system. As a matter of fact, prices and individual preferences determine the level of sales, being (V) the variable determined by the existing amount of money supply and individual preferences for cash balances. At any given prices, an increase in individual preferences for cash would decrease the amount of commodities exchanged until the new lower equilibrium prices are reached. At disequilibrium prices, individuals are not capable of selling or purchasing everything they planned to. Their plans are not realized, i.e. their notional demands do not match their effective or realized demands. Hence, excess supplies of commodities will exist for both individuals. Furthermore, an increase in the initial monetary endowments will increase the volume of commodities exchanged for money for any given not clearing prices. Hence, money is not neutral at disequilibrium prices.

Nevertheless, the excess of supplies in the commodity markets will not be balanced by an excess of demand in the money market which, on the other hand, contradicts Maurer's misguided attempt to prove the invalidity of Walras' Law. That is because individuals adjust their demand for commodities functions to accommodate their desired level of cash balances. Excess supplies in the commodity markets are not matched by an excess demand in the money market and Walras' Law does not hold, confirming that Malthusian general gluts are possible. As long as individuals are not constrained in the commodity markets and there are no limits to the incomevelocity of money, they can always adjust the volume of cash balances to their desired amount. When they are constrained in the commodity markets, individuals cannot acquire the desired level of commodities, they are forced to save and hence they will hold more cash balances than they have expected to hold, i.e. there is an excess demand for commodities and excess supply in the money market. Walras' Law does hold in this case although as we have seen it does not always hold and therefore it is not a Tautology.

\section{Conclusion}

Simplicity is one of Kuhn's five theoretical virtues. Although this paper has used simple economic theory to analyse the consequences of relaxing the assumption of automatic convertibility of commodities into nominal value, it has demonstrated that Walras' Law does not always hold.

\footnotetext{
${ }^{23}$ This assumption is in clear disagreement with the Radcliffe Committee Report. "We cannot find any reason for supposing or any experience in monetary history indicating, that there is any limit to the velocity of circulation of money" (Radcliffe report 1959, p. 133). The report was arguing against the Monetarist's Policies of Monetary Control, probably that is why it was termed by Jasay as the "Radcliffe Theory of Employment, Interest and Money" (Jasay 1960, pp. 170).

${ }^{24}$ This principle inspired Friedman's monetarist "k-percent rule" that the Central Bank should increase the money supply by a constant percentage rate to hit a predetermined inflationary target.

${ }^{25}$ The principle adopted in 1844 was abandoned after a run against English banks in 1847 probably due to the fact that high economic growth during that time in England had increased the demand for cash balances without a corresponding increase in available liquidity.

${ }^{26}$ The Gold standard was also blamed for the Great Depression in the U.S. See Eichengreen (1992).
} 
In monetary economies "commodities do not buy commodities" and hence there is always the necessity to transform commodity value into money value to purchase other commodities. A realization problem would imply that not all commodities are transformed into the demand capabilities of the system. Nevertheless, if Walras' Law holds in the two markets economy, an excess supply of commodities would be matched by an excess demand for money. However, as we have seen in section 3 the excess supply of commodities in the goods market might fail to be matched by an excess demand for money. Hence, Walras' Law does not hold and disequilibrium might not be compensatory, i.e. the money market might remain in equilibrium whilst there is excess supply in the commodity market. This result contradicts Maurer's analysis (2009) but it is actually the case when the prices of commodities are higher than the equilibrium levels as we have seen in section 3 .

Additionally, the result of the Sonnenschein-Mantel-Debreu (SMD) theorem, also called the impossibility theorem, that the market excess demand functions that can be generated from aggregating individual utility maximizing behaviour can take almost any form is not applicable as it relied on the validity of Walras' Law. With no restrictions of the excess demand functions there is no help to obtain stability and the methodological individualism approach has started to be questioned. ${ }^{27}$ However, the SMD theorem is not applicable in disequilibrium and hence there is no restriction on the individual utility maximizing behaviour that comes from Walras' Law. Hence, the market excess demand equations that result from aggregating individual utility maximization behaviour are not constrained by Walras' Law and Methodological Individualism is not the cause of the SMD impossibility theorem. It is Walras' Law that lead us into inextricable situations but in spite of the non-compensatory nature of disequilibrium, the natural tendency in a monetary exchange economy might still lead the economic system towards equilibrium. Additionally, the analysis of the stability of equilibrium can now be studied differently. Without the behavioural constraint inherent in Walras' Law, the system is now free from the SMD theorem and the Individualistic Methodology might not be incoherent as the basis of an analysis of the conditions for equilibrium. ${ }^{28}$

\section{References}

Buiter, Willen. 1975. On two specifications of asset equilibrium in macroeconomic models: A Note. Princeton University, ERP archives, n. 185.

Burstein, Michael. 1963. The index number problem, in Monetary Theory, edited by R.W.Clower, Penguin Books.

Chick, Victoria. 1995. Is there a case for Post Keynesian Economics, Scottish Journal of Political Economy, vol. 42 (1).

Clower, Robert Wayne. 1969. The Keynesian Counter-Revolution: A Theoretical Appraisal, in Monetary Theory, edited by R.W.Clower, Penguin Books.

Davidson, Paul. 1978. Money and the Real World. London, Macmillan, $2^{\text {nd }}$ ed.

Eichengreen, Barry. 1992. Golden Fetters: The Gold Standard and the Great Depression, 1919-1939. Oxford University Press.

Foley, Duncan. 1975. On two specifications of asset equilibrium in macroeconomic models. Journal of Political Economy, vol.83 (2).

Gali, Jordi. 2008. Monetary Policy, Inflation and the Business Cycle. An introduction to the New Keynesian Framework. Princeton University Press

Guerrien, Bernard. 1989. Concurrence, flexibilité et stabilité. Paris, Economica.

Gurley, John and Edward, Shaw. 1960. Money in a Theory of Finance. Washington, D.C., Brookings Institution.

Harris, Laurence. 1981. Monetary Theory. McGraw Hill.

Hicks, John. 1965. Capital and Growth. Oxford, Clarendon Press.

\footnotetext{
${ }^{27}$ See Kirman (1989) and Guerrien (1989).

${ }^{28}$ Forthcoming papers will analyse this question in a productive monetary economy with bonds.
} 
Jasay, A.E. (1960), The Working of the Radcliffe Monetary System, Oxford Economic Papers, New Series, vol.12, no.2, pp. 170-180

Kates, Steven. 1997. On the true meaning of Say's Law, Eastern Economic Journal, vol. 23 (2), pp. 191-202.

Keen, Steve. 2011. Debunking Macroeconomics, Economic Analysis and Policy,vol.41 (3).

Keynes, John Maynard. 1936. The General Theory of Employment, Interest and Money. http://www.marxists.org/reference/subject/economics/keynes/general-theory.

Kirman, Alan. 1989. The Intrinsic Limit of Modern Economic Theory: The Emperor has no clothes, The Economic Journal, vol.99, pp.126-139.

Lange, Oscar. 1942. Say's Law: A Restatement and Criticism. In O. Lange (ed.), Studies in Mathematical Economics and Econometrics, Chicago.

Maurer, Rainer Willi. 2009. The Invalidity of Walras' Law in Monetary Economies and the Resulting Money Price Determinacy. Discussion paper. Hochschule Pforzheim University.

Morishima, Michio. 1977. Walras' Economics: A Pure Theory of Capital and Money. Cambridge University Press.

Palley, Thomas. 1997. Walras' Law and Keynesian Macroeconomics". Available on the web: http://www.thomaspalley.com/docs/articles/macro_theory/walras_law.pdf. 1997.

Patinkin, Don. 1965. Money, Interest and Prices. Jointly published by Harper \& Row and John Weatherhill.

Radcliffe Committee. 1959. Committee on the workings of the Monetary System. Public record. The National Archives, Kew.

Rhodes, James Richard. 1984. Walras' Law and Clower's Inequality, Australian Economic Papers, vol.23 (42), p. 112-122.

Rhodes, James Richard. 1990. Walras' Law in Macroeconomic Disequilibrium: A reply, Australian Economic Papers, vol. 29.

Samuelson, Paul. 1969. Classical and New Classical Monetary Theory. In Monetary Theory edited by R.W.Clower, Penguin Books.

Walras, Leon. 1954. Elements of Pure Economics or the Theory of Social Wealth. Translated by W. Jaffé, London, Allen \& Unwin.

Wicksell, Knut (1898). Interest and prices: A study of the causes regulating the value of money. http://mises.org/sites/default/files/Interest\%20and\%20Prices_2.pdf.

Yeager, Leland and Rabin, Alan. 1997. Monetary aspects of Walras' Law and the stock-flow problem, Atlantic Economic Review, vol 25 (1). 


\section{Appendix A1}

(A.1-1)

$$
U^{1}\left(M_{1}, X\right)=A\left(M_{1}\right)^{\alpha} X^{1-\alpha}
$$

Subject to: $p_{x} X+M_{1}=p_{y} Y+\bar{M}_{1}$

$$
U^{2}\left(M_{2}, Y\right)=B\left(M_{2}\right)^{\beta} Y^{1-\beta}
$$

Subject to: $p_{y} Y+M_{2}=p_{x} X+\bar{M}_{2}$

Hence, from the maximization rules of utility functions we can obtain:

(A.1-3) $M_{1}=\frac{\alpha p_{x} X}{(1-\alpha)}=k_{1} p_{x} X$

(A.1-4) $M_{2}=\frac{\beta p_{y} Y}{(1-\beta)}=k_{2} p_{y} Y$

The system formed by the unrestricted budget constraint is as followed: ${ }^{29}$

$$
\begin{aligned}
& \text { (A1-5) } p_{y} Y+k_{2} p_{y} Y=p_{x} X+\bar{M}_{2} \quad(\mathrm{~A} 1-7) \mathrm{Y}^{\mathrm{R}}=\frac{\left(\mathrm{p}_{\mathrm{x}} \mathrm{X}^{\mathrm{R}}+\overline{\mathrm{M}}_{1}\right)}{\mathrm{p}_{\mathrm{y}}\left(1+\mathrm{k}_{1}\right)} \quad(\mathrm{A} 1-9) \mathrm{X}=\frac{\left(\overline{\mathrm{M}}_{1}+\overline{\mathrm{M}}_{2}+\mathrm{k}_{2} \overline{\mathrm{M}}_{1}\right)}{\mathrm{p}_{\mathrm{X}}\left(\mathrm{k}_{1}+\mathrm{k}_{2}+\mathrm{k}_{1} \mathrm{k}_{2}\right)} \\
& \text { (A1-6) } p_{x} X+k_{1} p_{x} X=p_{y} Y+\bar{M}_{1} \quad(\mathrm{~A} 1-8) \mathrm{X}^{\mathrm{R}}=\frac{\left(\mathrm{p}_{\mathrm{Y}} \mathrm{Y}^{\mathrm{R}}+\overline{\mathrm{M}}_{2}\right)}{\mathrm{p}_{\mathrm{X}}\left(1+\mathrm{k}_{2}\right)} \quad(\mathrm{A} 1-10) \mathrm{Y}=\frac{\left(\overline{\mathrm{M}}_{1}+\overline{\mathrm{M}}_{2}+\mathrm{k}_{1} \overline{\mathrm{M}}_{2}\right)}{\mathrm{p}_{\mathrm{Y}}\left(\mathrm{k}_{1}+\mathrm{k}_{2}+\mathrm{k}_{1} \mathrm{k}_{2}\right)}
\end{aligned}
$$

When $E D X+E D Y=0$

$$
\text { (A1-11) } \mathrm{p}_{\mathrm{X}}{ }^{\mathrm{w}}=\frac{\left(\overline{\mathrm{M}}_{1}+\overline{\mathrm{M}}_{2}+\mathrm{k}_{2} \overline{\mathrm{M}}_{1}\right)}{\overline{\mathrm{X}}\left(\mathrm{k}_{1}+\mathrm{k}_{2}+\mathrm{k}_{1} \mathrm{k}_{2}\right)}
$$

Walrasian prices.

$$
(\mathrm{A} 1-12) \mathrm{p}_{\mathrm{y}}{ }^{\mathrm{w}}=\frac{\left(\overline{\mathrm{M}}_{1}+\overline{\mathrm{M}}_{2}+\mathrm{k}_{1} \overline{\mathrm{M}}_{2}\right)}{\overline{\mathrm{Y}}\left(\mathrm{k}_{1}+\mathrm{k}_{2}+\mathrm{k}_{1} \mathrm{k}_{2}\right)}
$$

Hence, if $p_{X}{ }^{d}=p_{X}{ }^{w}+d x$ and $p_{y}{ }^{d}=p_{y}{ }^{w}+d y$ the demand functions are:

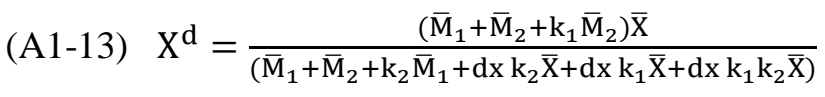 $\frac{\partial \mathrm{X}^{\mathrm{d}}}{\partial d x}<0$
(A1-14) $\quad \mathrm{Y}^{\mathrm{d}}=\frac{\left(\overline{\mathrm{M}}_{1}+\overline{\mathrm{M}}_{2}+\mathrm{k}_{1} \overline{\mathrm{M}}_{2}\right) \overline{\mathrm{Y}}}{\left(\overline{\mathrm{M}}_{1}+\overline{\mathrm{M}}_{2}+\mathrm{k}_{1} \overline{\mathrm{M}}_{2}+\mathrm{dy} \mathrm{k}_{1} \overline{\mathrm{Y}}+\mathrm{dy}_{2} \overline{\mathrm{Y}}+\mathrm{dy} \mathrm{k}_{1} \mathrm{k}_{2} \overline{\mathrm{Y}}\right)}$ $\frac{\partial Y^{\mathrm{d}}}{\partial d y}<0$
(A1-15) $\quad Y=p_{x} \mathrm{X}^{\mathrm{d}}+p_{y} \mathrm{Y}^{\mathrm{d}}=V \cdot \mathrm{M} \quad$ and $\quad V=\frac{(2 \widetilde{\mathrm{M}}+\mathrm{k} 2 \widetilde{\mathrm{M}} 1+\mathrm{k} 1 \widetilde{\mathrm{M}} 2)}{(\mathrm{k} 1+\mathrm{k} 2+\mathrm{k} 1 \mathrm{k} 2) \mathrm{M}}$
(A1-16) $\quad E D M=0$

\footnotetext{
${ }^{29}$ Appendix A2 analyses the budget constraint including "service d'approvisionnement".
} 


\section{Appendix A2}

When budget constraints include monetary and commodity services the equations would be as following:

$(\mathrm{A} 2-1) p_{y} Y+p_{y}^{\prime} Y^{\prime}+p_{m} M_{1}+p_{m}^{\prime} M_{1}=p_{x} X+p_{y}^{\prime} Y^{\prime}+p_{m} \bar{M}_{1}+p_{m}^{\prime} \bar{M}_{1}$

$(\mathrm{A} 2-2) p_{x} X+p_{x}^{\prime} X^{\prime}+p_{m} M_{2}+p_{m}^{\prime} M_{2}=p_{y} Y+p_{x}^{\prime} X^{\prime}+p_{m} \bar{M}_{2}+p_{m}^{\prime} \bar{M}_{2}$

Individual 1 demands $\left(M_{1}\right)$ as the expected amount of cash balances for transaction purposes. When commodity prices are taken as relative prices respect to the monetary unit, the relative price of money is taken as 1 and then $p_{m}^{\prime}=i p_{m}$. Patinkin assumes that $p_{m}=\frac{1}{p}$ the price of money is equal to the reciprocal of the absolute price level. ${ }^{30}$ However, in Walras the price of money is always referred to a numeraire. Furthermore, if money is taken as the numeraire then $p_{m}=1$ and $p_{m}^{\prime}=i$. Walras assumed that the demand for money does not depend on $\left(p_{m}^{\prime}\right)$ except very weakly. ${ }^{31}$ There might be five reasons why Walras assumed a weak relationship between $\left(p_{m}^{\prime}\right)$ and the demand for money.

1.Certainty. Individuals will not need extra balances for transaction purposes if they know how much cash balances they will require.

2. Trust. If individuals are operating in an environment where trust among them is guaranteed, transactions will take place even before payment is secured.

3. Short-term Credit. Individuals agree to supply commodities before payment.

4. High elasticity of substitution between cash balance and commodity services. If individuals have a higher preference for money balances the equilibrium interest rates would be lower.

5.Precautionary balances. Holding additional balances further guarantees that the individual will not be running out of liquidity when it is most needed.

We can see that the money market is always in equilibrium for prices higher than the Walrasian price vector. However, the commodity market clearance will depend on prices.

\footnotetext{
30 "It Should be clear that $p_{u}$ is analogous to the reciprocal of the absolute price level" (Patinkin, 1965, p. $551)$.

31 “(...) mais que, toutefois, ils n'en dépendent que très indirectement et très faiblement” (Walras in Patinkin 1965, p.559).
} 